ARTICLE

DOI: $10.1038 /$ ncomms 15898

OPEN

\title{
Adaptive self-assembly and induced-fit transformations of anion-binding metal-organic macrocycles
}

Ting Zhang ${ }^{1,2}$, Li-Peng Zhou' ${ }^{1}$ Xiao-Qing Guo ${ }^{1}$, Li-Xuan Cai ${ }^{1} \&$ Qing-Fu Sun ${ }^{1}$

Container-molecules are attractive to chemists due to their unique structural characteristics comparable to enzymes and receptors in nature. We report here a family of artificial self-assembled macrocyclic containers that feature induced-fit transformations in response to different anionic guests. Five metal-organic macrocycles with empirical formula of $M_{n} L_{2 n}$ $(M=$ Metal; $L=$ Ligand; $n=3,4,5,6,7)$ are selectively obtained starting from one simple benzimidazole-based ligand and square-planar palladium(II) ions, either by direct anion-adaptive self-assembly or induced-fit transformations. Hydrogen-bonding interactions between the inner surface of the macrocycles and the anionic guests dictate the shape and size of the product. A comprehensive induced-fit transformation map across all the $M_{n} L_{2 n}$ species is drawn, with a representative reconstitution process from $\mathrm{Pd}_{7} \mathrm{~L}_{14}$ to $\mathrm{Pd}_{3} \mathrm{~L}_{6}$ traced in detail, revealing a gradual ring-shrinking mechanism. We envisage that these macrocyclic molecules with adjustable well-defined hydrogen-bonding pockets will find wide applications in molecular sensing or catalysis.

\footnotetext{
${ }^{1}$ State Key Laboratory of Structural Chemistry, Fujian Institute of Research on the Structure of Matter, Chinese Academy of Sciences, Fuzhou 350002, China. ${ }^{2}$ College of Chemistry, Fuzhou University, Fuzhou 350108, China. Correspondence and requests for materials should be addressed to Q.-F.S.

(email: qfsun@fjirsm.ac.cn).
} 
C oordination-driven self-assembly has become one of the most convenient strategies for the bottom-up construction of functional molecular ensembles ${ }^{1-5}$. On the basis of elaborate symmetry considerations, numerous two-dimensional (2D) and three-dimensional (3D) architectures have been obtained in ease by the simple combination of designed ligands (L) and metal ions (M), which show great potential in the modulation of reactivity and/or photoelectric properties of guest molecules by encapsulation ${ }^{6-10}$. To ensure the directed assembly, rigid ligands are most often employed ${ }^{5,11,12}$. Flexible ligands, which usually give rise to interconvertible architectures, are far less utilized in coordination-directed self-assembly ${ }^{13}$. However, assemblies available in nature favour flexibility over rigidity. For example, enzymes are rather flexible structures, the active site of which is continuously reshaped by interactions with specific substrates, following the so called induced-fit mechanism $^{14}$.

Anion receptor chemistry has witnessed great advances in the past decades. This area of supramolecular chemistry has a number of potential applications in biology, environment and the food industry ${ }^{15-17}$. The fast developing coordination-driven supramolecular chemistry has provided enormous examples of metal-organic assembled systems that can recognize, respond to, or sense negative-charged species ${ }^{18-22}$. However, most metal-organic receptors reported so far are of invariant structures, aiming to reach high selectivity towards targeting anions. Adaptive anion receptors, that is, receptors that can continuously transform its shape and size to maximize the binding interactions with different anions, remain elusive ${ }^{23-26}$. For example, seminal work by Hasenknopf et al. ${ }^{23}$ has shown that use of flexible tris-bipy ligands and iron(II) lead to the formation of a dynamic combinatorial system ${ }^{27-29}$, where a set of circular helicates is expressed depending on the anions present during the self-assembly process.

Herein, we report an artificial assembly system that features adaptive self-assembly and induced-fit transformation properties in the presence of anionic guests. A family of metal-organic macrocycles with the general formula of $\mathrm{Pd}_{n} \mathrm{~L}_{2 n}(n=3,4,5,6,7)$ are selectively obtained starting from one simple ligand and square-planar $\mathrm{Pd}^{\mathrm{II}}$ ions. Hydrogen bonding between the inner surface of the macrocycles and the bound guests, different anions in this case, dictates the shape and size of the final product. In situ anion-adaptive self-assembly gives rise to the $\mathrm{Pd}_{n} \mathrm{~L}_{2 n}$ species for $n=3,6$, 7. For $n=4,5$, post-synthetic transformations ${ }^{26,30-34}$ from other macrocycles are employed, featuring an induced-fit transformation process. Five distinct macrocycles are clearly characterized by NMR, ESI-TOF-MS, and in the case of $n=3,4$, 5,6 by single crystal X-ray diffraction. Moreover, a comprehensive map showing all the transformations across the macrocyclic species was drawn, with a representative reconstitution process from $\mathrm{Pd}_{7} \mathrm{~L}_{14}$ to $\mathrm{Pd}_{3} \mathrm{~L}_{6}$ traced in detail by titration experiments, revealing a gradual ring-shrinking mechanism.

\section{Results}

Syntheses and characterization of metal-organic macrocycles 2-6. It is well-established that self-assembly of rigid planer bidentate pyridinyl ligands with specific bent angles and square-planar $\mathrm{Pd}^{\mathrm{II}}$ ions will lead to a group of $\mathrm{Pd}_{n} \mathrm{~L}_{2 n}$ molecular spheres ${ }^{35-42}$. Considering the inherent topological relationships, we propose that macrocyclic complexes may also be obtained when the ligand is nonplanar ${ }^{43}$. In this study, we choose a very simple nonplanar bidentate ligand (1) and $\mathrm{Pd}^{\mathrm{II}}$ ions as our building blocks (Fig. 1). Ligand 1 has two unique features: first it is not conjugated, so that two benzoimidazole rings are reasonably free to rotate and bent,

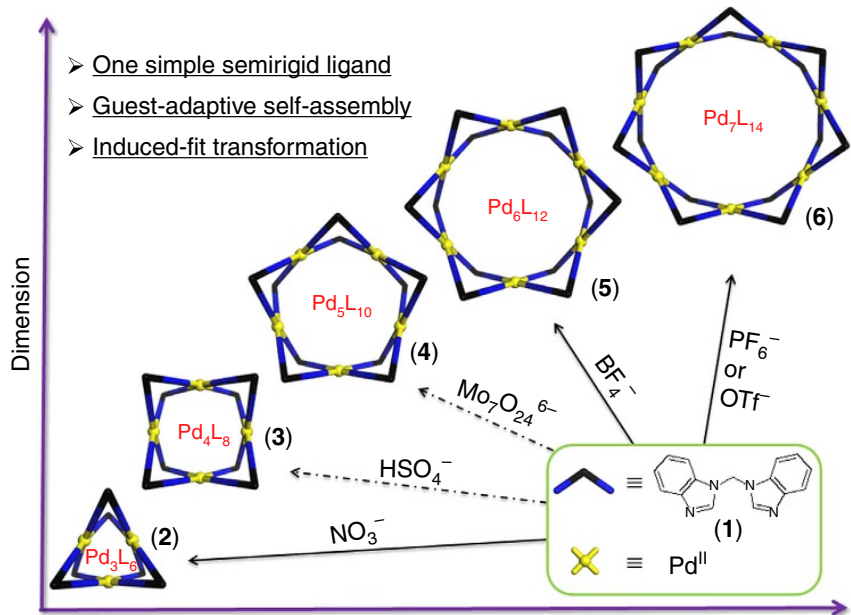

Number of components

Figure 1 | Self-assembly of anion-binding metal-organic macrocycles. Self-assembly of anion-binding metalorganic macrocycles with an empirical formula of $\mathrm{Pd}_{n} \mathrm{~L}_{2 n}(n=3,4,5,6,7)$. Dashed arrows indicate that $\mathrm{Pd}_{4} \mathrm{~L}_{8}$ and $\mathrm{Pd}_{5} \mathrm{~L}_{10}$ were obtained by induced-fit transformation from other macrocycles instead of direct self-assembly.

giving rise to the conformational flexibility of its coordination geometry ${ }^{44}$; and second benzoimidazole bears an acidic $\mathrm{CH}$ bond that can act as hydrogen-bond donor, especially after its coordination to a metal ${ }^{45,46}$. In fact, varieties of anion-binding hosts utilizing the imidazole motif, either of pure organic or metal-organic forms, have been reported ${ }^{47}$. We envisage that anions with different size and shape will dictate the arrangement of ligand 1 during the self-assembly process, thus providing the driving force for the otherwise complicated system towards thermodynamically preferable outcome.

Reaction of ligand $1(20.07 \mu \mathrm{mol})$ with a half equivalent of $\mathrm{Pd}\left(\mathrm{NO}_{3}\right)_{2}(10.04 \mu \mathrm{mol})$ in $1 \mathrm{ml}$ dimethyl sulfoxide ([D $\left.]_{6} \mathrm{DMSO}\right)$ at $70{ }^{\circ} \mathrm{C}$ for $5 \mathrm{~h}$ leads to the quantitative formation of a single compound, as confirmed by ${ }^{1} \mathrm{H}$ NMR spectroscopy (Fig. 2a,b). Compared with the free ligand, the peak of $\mathrm{H}_{\mathrm{e}}$ on benzimidazole of the assembly was shifted downfield from 8.77 to 9.00 p.p.m., suggesting the loss of electron density on the imidazole ring due to coordination or the involvement of Hydrogen bonding. The diastereotopic environment of the methylene protons, which split into a pair of doublets in a 1:1 ratio, indicates a cis conformation of the ligands in the product ${ }^{44}$. Diffusion-ordered NMR spectrum (DOSY) (Supplementary Fig. 4) confirmed that all peaks have the same diffusion coefficient, with an estimated diameter of $1.12 \mathrm{~nm}$ for the assembly. The composition of product formulated as $\mathrm{Pd}_{3} \mathrm{~L}_{6}\left(\mathrm{NO}_{3}\right)_{6}(2)$ was then clearly provided by high-resolution ESI-TOF-MS. Prominent peaks observed at $m / z=1028.1468$, and 665.1049 correspond to the multiple-charged $\left[2-\left(\mathrm{NO}_{3}^{-}\right)_{n}\right]^{n+} \quad(n=2,3)$ molecular-ion signals, with consecutive loss of the $\mathrm{NO}_{3}^{-}$counter-ions. Moreover, the isotopic patterns of each resolved peaks were also in good agreement with the simulated values (Fig. $2 \mathrm{~g}$ ).

To our surprise, a clearly distinct product was obtained when $\mathrm{Pd}\left(\mathrm{BF}_{4}\right)_{2}$ was used during the self-assembly, in a similar reaction condition as described above (See Methods section for details). As shown in Fig. 2e, all the proton signals of the ligand on this complex strongly split into two sets in a 1:1 ratio, with one set of signals obviously downfield shifted and the other upfield shifted (except for the $\mathrm{CH}$ on imidazole) with respect to those of the free ligand. Such observation is clearly different from the trinuclear compound 2 , where only the protons on the methylene groups are split. This suggests two different chemical 

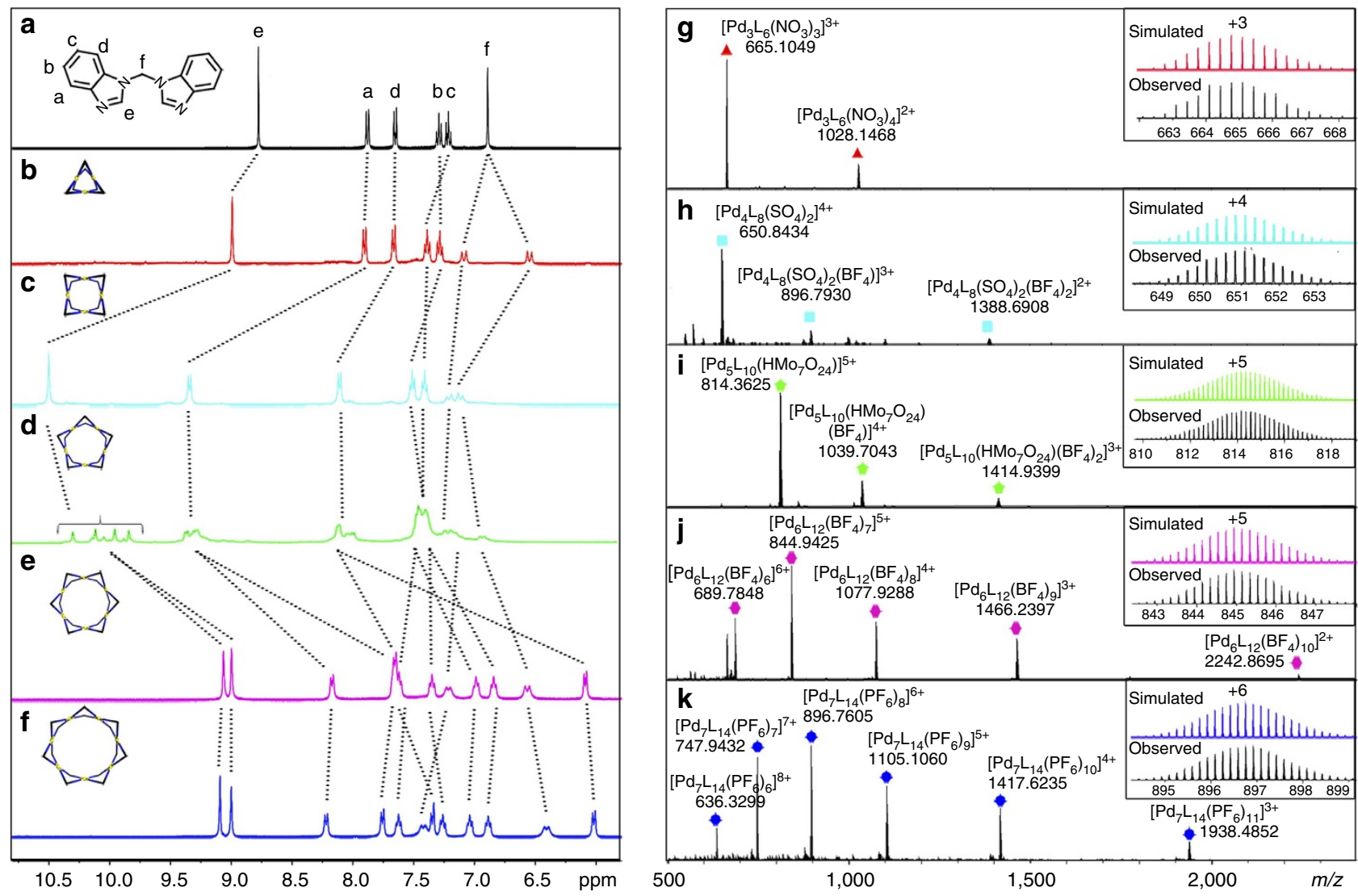

Figure $\left.2\right|^{\mathbf{1}} \mathbf{H}$ NMR and ESI-TOF-MS spectra. (a-f) are ${ }^{1} \mathrm{H}$ NMR $\left(400 \mathrm{MHz},\left[\mathrm{D}_{6}\right] \mathrm{DMSO}, 298 \mathrm{~K}\right)$ spectra for free ligand $\mathbf{1}$ and the complexes $\mathbf{2}, \mathbf{3}, \mathbf{4}, \mathbf{5}, \mathbf{6}$ respectively; (g-k) are ESI-TOF-MS spectra for complexes 2, 3, 4, $\mathbf{5}$ and $\mathbf{6}$ with insets showing the representative observed and calculated isotope patterns.

environments for the benzoimidazole moities in the final product. On the basis of ${ }^{1} \mathrm{H}^{-1} \mathrm{H}$ COSY experiment, all the signals could be fully assigned (Supplementary Fig. 8). DOSY spectrum (Supplementary Fig. 9) reveals the formation of a new product with an estimated diameter of $2.23 \mathrm{~nm}$, which is dramatically larger than that of 2. ESI-TOF-MS (Fig. 2j) discloses that this complex is formulated as $\mathrm{Pd}_{6} \mathrm{~L}_{12} \cdot\left(\mathrm{BF}_{4}\right)_{12}$ (5), with prominent peaks observed at $m / z=689.7848,844.9425, \quad 1077.9288$, 1466.2397 and 2242.8695 , corresponding to $\left[5-\left(\mathrm{BF}_{4}^{-}\right)_{n}\right]^{n+}$ $(n=2-6)$.

On the basis of this unexpected structural switch from $\mathrm{Pd}_{3} \mathrm{~L}_{6}$ to $\mathrm{Pd}_{6} \mathrm{~L}_{12}$ by varing the counter ions from $\mathrm{NO}_{3}^{-}$to $\mathrm{BF}_{4}^{-}$, we then postulate that other counter ions with larger size may induce the formation of higher nuclear assembly. Indeed, pure heptanuclear $\mathrm{Pd}_{7} \mathrm{~L}_{14} \cdot\left(\mathrm{PF}_{6}\right)_{14}(\mathbf{6 a})$ or $\mathrm{Pd}_{7} \mathrm{~L}_{14}(\mathrm{OTf})_{14}(\mathbf{6 b})$ complexes were quantitatively obtained by replacing the metal source with $\mathrm{Pd}\left(\mathrm{PF}_{6}\right)_{2}$ or $\mathrm{Pd}(\mathrm{OTf})_{2}$, respectively, the composition of which were determined in a similar manner by NMR and ESI-TOF-MS (Fig. 2f,k and Supplementary Figs 13-21). Similar diastereotopic splitting of ${ }^{1} \mathrm{H}$ NMR signals into 1:1 ratio was also observed for compound 6.

Direct synthesis of the missing $\operatorname{Pd}_{n} \mathrm{~L}_{2 n}$ macrocycles between $n=3$ and 6 were unsuccessful. Instead, the intermediate-sized $\mathrm{Pd}_{4} \mathrm{~L}_{8}$ and $\mathrm{Pd}_{5} \mathrm{~L}_{10}$ could be obtained by anion-induced transformation processes. In a typical procedure, tetrabutylammonium hydrogen sulfate $(10.27 \mathrm{mg}, 30.24 \mu \mathrm{mol}$, 4.5 eq.) was added to a $1 \mathrm{ml}\left[\mathrm{D}_{6}\right] \mathrm{DMSO}$ solution of compound $5(6.72 \mu \mathrm{mol})$ and the mixture was heat at $70^{\circ} \mathrm{C}$ for $3 \mathrm{~h}$. 1D (Fig. 2c) and 2D NMR (Supplementary Figs 25 and 26) indicated the total transformation of $\mathbf{5}$ into a new product. In the ${ }^{1} \mathrm{H}$ NMR, the diagnostic diastereomeric splitting of the ligands signals on $\mathbf{5}$ gradually disappeared with the origin of another single set of signals (except for the methylene protons). Moreover, $\mathrm{H}_{\mathrm{e}}$ on the imidazole rings were significantly shifted downfield from 8.75 p.p.m. and 7.86 p.p.m. to 10.46 p.p.m.), indicating the involvement of strong Hydrogenbonding interactions with the bisulfate ions. DOSY revealed that the new complex was of a diameter of $1.51 \mathrm{~nm}$, a value in between of the compound 2 and $\mathbf{5}$. Even with intrinsic mixed counter anions, ESI-TOF-MS spectrum clearly confirmed the formation of the tetranuclear $\mathrm{Pd}_{4} \mathrm{~L}_{8}$ compound (3), with prominent peaks observed at $\mathrm{m} / z=650.8434$, $896.7930,1388.6908$, corrsponding to $\left[\mathrm{Pd}_{4} \mathrm{~L}_{8}\left(\mathrm{SO}_{4}\right)_{2}\right]^{4+}$, $\left[\mathrm{Pd}_{4} \mathrm{~L}_{8}\left(\mathrm{SO}_{4}\right)_{2}\left(\mathrm{BF}_{4}\right)_{1}\right]^{3+}, \quad\left[\mathrm{Pd}_{4} \mathrm{~L}_{8}\left(\mathrm{SO}_{4}\right)_{2}\left(\mathrm{BF}_{4}\right)_{2}\right]^{2+}$, respectively. The loss of protons on bisulfates anions was possibly due to the total $8+$ charge on the host or the presence of multiple Hydrogen bonding between the host and anions. Under similar conditions, induced-fit transformation from 6 to $\mathbf{3}$ was also quantitative (see discussion below).

The conversion from $M_{6} L_{12}$ to the $\mathrm{M}_{5} \mathrm{~L}_{10}$ structure was beyond anticipation. Our initial thought was to induce the formation of higher-nuclear $\mathrm{Pd}_{n} \mathrm{~L}_{2 n}$ complexes (for $n>7$ ), using bulkier counter-ions. However, treating compound $5(6.72 \mu \mathrm{mol})$ with 0.8 eq. tetrabutylammonium heptamolybdate $\left(\left(t-\mathrm{Bu}_{4} \mathrm{~N}\right)_{6} \mathrm{Mo}_{7} \mathrm{O}_{24}\right.$, $13.48 \mathrm{mg}, 5.38 \mu \mathrm{mol})$ in $1 \mathrm{ml}\left[\mathrm{D}_{6}\right]$ DMSO solution converted 5 into $\mathrm{Pd}_{5} \mathrm{~L}_{10}$ (4) (same conditions as above). The formation of this new complex was indicated by ${ }^{1} \mathrm{H}$ NMR (Fig. 2d), where all signals become severely broadened with the $\mathrm{H}_{\mathrm{e}}$ significantly split into a complicated pattern, presumably due to a mismatch of symmetry between the host and the guest anion. However, ${ }^{1} \mathrm{H}$ NMR at $100^{\circ} \mathrm{C}$ becomes much simplified (Supplementary Fig. 30). In particular, the complicated pattern observed for $\mathrm{H}_{\mathrm{e}}$ 
a

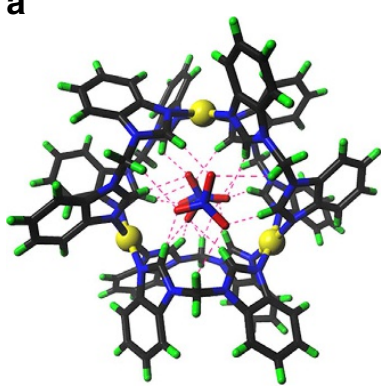

b

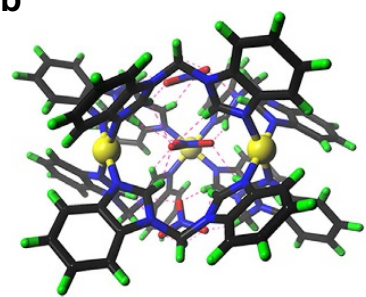

C

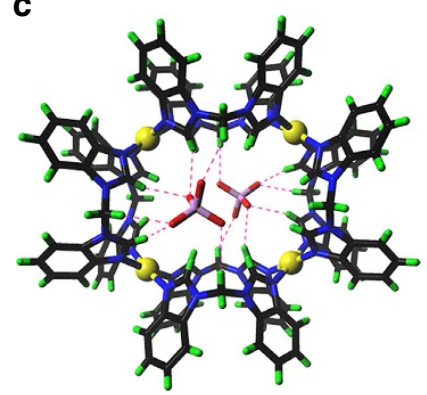

d

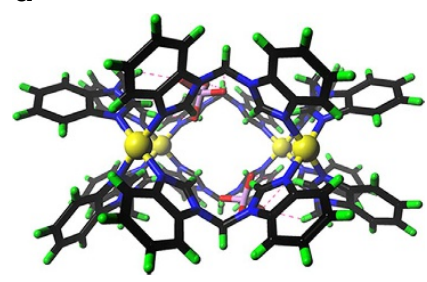

Figure 3 | X-ray single crystal structures of compounds $\mathbf{2}$ and 3. Top (a,c) and side (b,d) views of the X-ray crystal structures of compounds $\mathbf{2}$ and $\mathbf{3}$. (Colour scheme: $\mathrm{H}$ bondings, red dashed lines; Pd, yellow; C, black; $\mathrm{N}$, blue; $\mathrm{S}$, pink; $\mathrm{O}$, red; $\mathrm{H}$, green. Solvents and anions located outside the macrocycles are omitted for clarity.)

coalesced into one single broadened peak with clear upfield-shifting, indicating the break of $\mathrm{H}$ bonds and increase of symmetry at elevated temperatures. DOSY revealed that the new complex was of a diameter of $1.84 \mathrm{~nm}$ (Supplementary Fig. 34). ESI-TOF-MS reveals that a new pentanuclear $\mathrm{Pd}_{5} \mathrm{~L}_{10}$ compound (4) with an encapsulated $\left[\mathrm{HMo}_{7} \mathrm{O}_{24}\right]^{5-}$ cluster was formed, with prominent peaks observed at $\mathrm{m} / z=814.3625,1039.7043$ and 1414.9399 corresponding to $\left[\mathrm{Pd}_{5} \mathrm{~L}_{10}\left(\mathrm{HMo}_{7} \mathrm{O}_{24}\right)_{1}\right]^{5+}, \quad\left[\mathrm{Pd}_{5} \mathrm{~L}_{10}\left(\mathrm{HMo}_{7} \mathrm{O}_{24}\right)_{1}\left(\mathrm{BF}_{4}\right)_{1}\right]^{4+}$ and $\left[\mathrm{Pd}_{5} \mathrm{~L}_{10}\left(\mathrm{HMo}_{7} \mathrm{O}_{24}\right)\left(\mathrm{BF}_{4}\right)_{2}\right]^{3+}$, respectively (Fig. 2i).

The structures of the self-assembled $\mathrm{Pd}_{n} \mathrm{~L}_{2 n}$ complexes for $n=3,4,5,6$ were unambiguously determined by single crystal diffraction studies facilitated by high-power X-ray source at the Shanghai Synchrotron Radiation Facility (SSRF). Crystal structures reveal that all complexes shares a similar donut-shaped structure, where $2 n$ bent bidentate ligands are connected by $n$ square-planar coordinated $\mathrm{Pd}^{\mathrm{II}}$ ions in a cyclic fashion. Ligands can be divided into two layers by an imaginary plane of the metal centres. On the basis of crystal structures, we can clearly see that hydrogen-bonding interactions between the host framework and its entrapped anions played an important role in dictating the size of the macrocycles.

High quality single crystals of compound $\mathbf{2}$ suitable for crystallographic analysis were obtained by slow vapour diffusion of dichloromethane (DCM) into a DMSO solution of the complex over 3 weeks, which crystallized in a $P_{-1}$ space group with two macrocycles sitting in the unit cell. This smallest donut-shaped assembly has an out diameter of $1.74 \mathrm{~nm}$ and a height of $0.87 \mathrm{~nm}$, which can be regarded as a trimeric structure consisting three $\mathrm{Pd}_{2} \mathrm{~L}_{2}$ square building blocks by sharing the $\mathrm{Pd}^{\mathrm{II}}$ centres (Fig. 3a,b). Interestingly, three nitrate anions were $\mathrm{H}$ bonded inside the cavity, which form a three-layered sandwich conformation. One $\mathrm{NO}_{3}^{-}$is in a perpendicular orientation to the other two parallel ones, possibly due to electrostatic repulsion. Each nitrate is involved in at least six Hydrogen-bonding interactions with the inward $\mathrm{CH}$ from the imidazole and methylene groups. We propose these multi-point $\mathrm{H}$ bonds act as glues to tie the ligand strands together. Similarly, diffusion of

DCM into a DMSO solution of 3 resulted in the crystalization of this tetranuclear species (Fig. 3c,d). Two $\mathrm{SO}_{4}^{2-}$ are encapsulated inside the cavity in this case, each of which is sextuple $\mathrm{H}$ bonded with three ligands on the same layer.

Crystals for the $\mathrm{Pd}_{5} \mathrm{~L}_{10}$ complex (4) were also obtained by a similar method described above. The pentagonal topology of the framework was clearly confirmed (Fig. 4a,b). Possibly due to the mismatch of symmetry in this host-guest complex, modelling of the encapsulated $\mathrm{HMo}_{7} \mathrm{O}_{24}^{5-}$ anion with the known connectivity $^{48,49}$ were unsuccessful and its contribution was removed by the SQUEEZE routine $\mathrm{e}^{50}$. We propose that the $\mathrm{HMo}_{7} \mathrm{O}_{24}^{5}$ guest inside the confined cavity is severely disordered or adopting an unusual geometry. It has to be pointed out that the nature of the encapsulated $\left[\mathrm{HMo}_{7} \mathrm{O}_{24}\right]^{5-}$ cluster is unclear at this stage and detailed host-guest chemistry of these macrocycles with polyoxometalates deserves further study. After a long trail-and-error, high quality single crystals of $\mathbf{5}$ were fortunately obtained by a co-crystallization method with 1.0 eq. of $\mathrm{NaB}(\mathrm{ArF})_{4}$ $\left(\mathrm{ArF}=3,5\right.$-bis(trifluoromethyl)phenyl). At this condition, ${ }^{1} \mathrm{H}$ or ${ }^{19}$ F NMR (Supplementary Figs 10 and 11 ) did not show obvious chemical shift for both the host and the $\left[\mathrm{B}(\mathrm{ArF})_{4}\right]^{-}$anion, indicating that there is no strong interaction between them. Compound 5 crystallized in an orthogonal $\mathrm{R}_{-3 c}$ space group with a huge unite cell volume of $119,056 \AA^{3}$ (Fig. $4 c, d$ ). The dimension of this self-assembled macrocycle spans an out diameter of $2.24 \mathrm{~nm}$ and inner diameter of $1.19 \mathrm{~nm}$. Compared to the symmetrical $\mathrm{Pd}_{2} \mathrm{~L}_{2}$ squares units existing on the crystal structures of $\mathbf{2 , 3}$ and $\mathbf{4}$, the six $\mathrm{Pd}_{2} \mathrm{~L}_{2}$ units on $\mathbf{5}$ were severely distorted into a rectangular conformation, which provides a good reason for the split signals observed in its ${ }^{1} \mathrm{H}$ NMR. Such structural distortion also reflects the flexibility of ligand 1. Due to the low-diffraction nature of this sample, only the $\operatorname{Pd}_{6} L_{12}$ connectivity was confirmed and no detailed anion binding mode could be modelled. In crystal packing, two giant channels are present along the $c$ axis due to layer-by-layer stacking of the ring-shaped complexes, one of which is defined by the ring cavity with a diameter of $1.19 \mathrm{~nm}$, the other is $1.75 \mathrm{~nm}$ encircled by six adjacent molecules, where we hypothesize is filled with the highly disordered bulky $\left[\mathrm{B}(\mathrm{ArF})_{4}\right]^{-}$anions. Many attempts to crystallize the heptanuclear $\mathbf{6}$ were unsuccessful, possibly due to its low symmetry and big size. This structure was then modelled by molecular mechanical optimizations and depicted in Fig. 4e,f.

\section{Discussion}

Taking advantage of the anion-adaptivity observed during the self-assembly, we then managed to draw a comprehensive map detailing the induced-fit transformation processes between all species of the family (Fig. 5a and Supplementary Figs 42-58). First of all, we found that addition of 30 eq. of $\mathrm{KNO}_{3}$ to the $\mathrm{Pd}_{7} \mathrm{~L}_{14}$ complex $\left(\mathrm{PF}_{6}^{-}\right.$salt) or $\mathrm{Pd}_{6} \mathrm{~L}_{12}$ complex 5 resulted in the quantitative transformation to $\mathrm{Pd}_{3} \mathrm{~L}_{6}$. The $\left(\mathrm{Mo}_{7} \mathrm{O}_{24}\right) @ \mathrm{Pd}_{5} \mathrm{~L}_{10}$ was found to be the the most stable host-guest complex for this dynamic combinatorial system, which could be quantitatively obtained by additon of $\left(t-\mathrm{Bu}_{4} \mathrm{~N}\right)_{6} \mathrm{Mo}_{7} \mathrm{O}_{24}$ to either compounds 2 , 3, 5 or 6. In fact, this host-guest complex is so stable that once formed it will never transform into other macrocycles. Similarly, $\mathrm{Pd}_{3} \mathrm{~L}_{6}$ could be quantitatively obtained by the templation effect of the $\mathrm{NO}_{3}^{-}$anion starting from $\mathrm{Pd}_{4} \mathrm{~L}_{8}$, $\mathrm{Pd}_{6} \mathrm{~L}_{12}$ or $\mathrm{Pd}_{7} \mathrm{~L}_{14} \cdot \mathrm{SO}_{4}^{2-}$, on the contrary, is a weaker template comparing to $\mathrm{NO}_{3}^{-}$, possibly due to the fact that $\mathrm{Pd}_{3} \mathrm{~L}_{6}$ can encapsulate three $\mathrm{NO}_{3}^{-}$while $\mathrm{Pd}_{4} \mathrm{~L}_{8}$ can only host two $\mathrm{SO}_{4}^{2-}$. Meanwhile, transformation from $\mathrm{Pd}_{7} \mathrm{~L}_{14}$ to $\mathrm{Pd}_{6} \mathrm{~L}_{12}$ was obtained in only $80 \%$ yield even if 35 eq. of $\mathrm{BF}_{4}^{-}$anion was used, suggesting only a subtle energy difference between them. On the basis of this map, a sequence of templating-effect like 
a

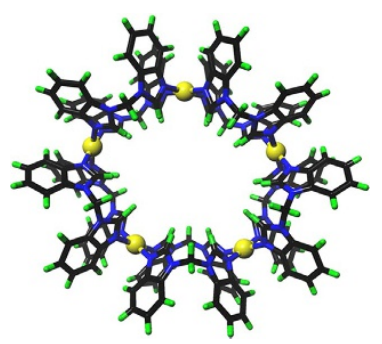

b

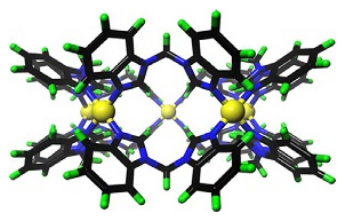

C

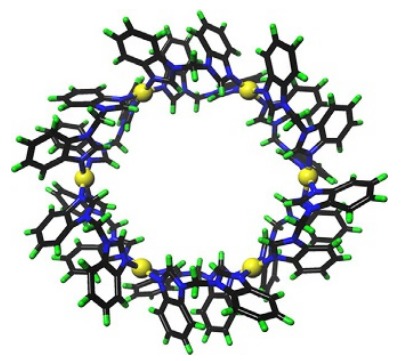

d

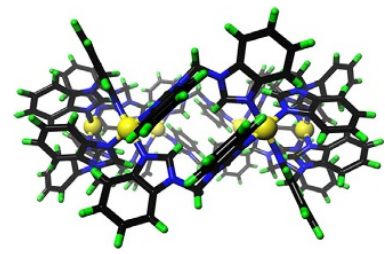

e

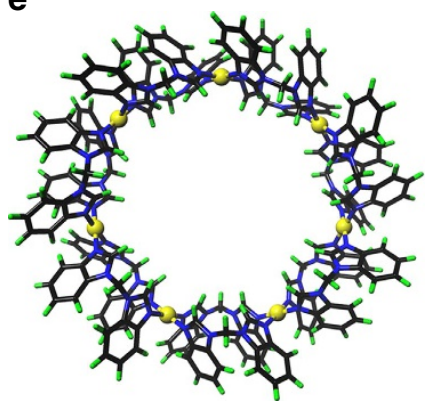

f



Figure 4 | X-ray single crystal structures of compounds 4, 5 and simulated structures of complex 6. Top (a,c) and side (b,d) views for the X-ray crystal structures of complexes $\mathbf{4}$ and 5; (e,f) are similar views for the simulated structure of complex $\mathbf{6}$. (Same colour schemes were used as for Fig. 3.)



b



C

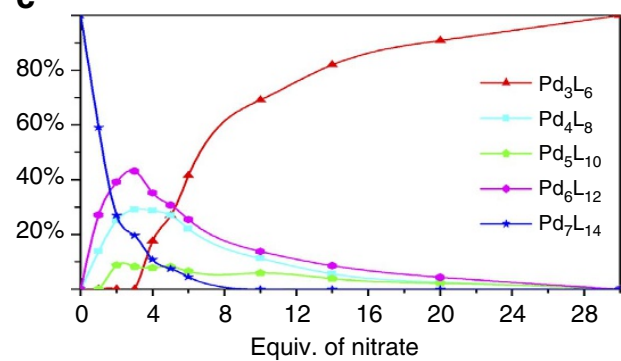

Figure 5 | Induce-fit transformations between macrocycles. (a) Cross map showing all the transformations between the macrocyclic species (conditions for a: $\left.\mathrm{NO}_{3}^{-} ; \mathrm{b}: \mathrm{HSO}_{4}^{-} ; \mathrm{c}: \mathrm{Mo}_{7} \mathrm{O}_{24}^{6} ; \mathrm{d}_{\mathrm{BF}}^{-}\right) ;(\mathbf{b})^{1} \mathrm{H} \mathrm{NMR}\left(400 \mathrm{MHz},\left[\mathrm{D}_{6}\right] \mathrm{DMSO}, 298 \mathrm{~K}\right)$ titration spectra showing the gradual transformation from the heptanuclear complex $\mathbf{6} \mathbf{a}$ to the trinuclear complex $\mathbf{2}$ by sequential addition of $\mathrm{KNO}_{3}$ (bottom up: 0, 1, 2, 4, 10, 30 eq.) with $\mathrm{H}_{\mathrm{e}}$ signals highlighted for $\mathrm{Pd}_{3} \mathrm{~L}_{6}$ : red, $\mathrm{Pd}_{4} \mathrm{~L}_{8}$ : sky blue, $\mathrm{Pd}_{5} \mathrm{~L}_{10}$ : green, $\mathrm{Pd}_{6} \mathrm{~L}_{12}$ : pink and $\mathrm{Pd}_{7} \mathrm{~L}_{14}$ : dark blue, respectively; (c) Composition distributions for all the $\mathrm{Pd}_{n} \mathrm{~L}_{2 n}$ species obtained by the integrals of the $\mathrm{H}_{\mathrm{e}}$ signals from the titration experiment.

$\mathrm{Mo}_{7} \mathrm{O}_{24}^{6-}>\mathrm{NO}_{3}^{-}>\mathrm{SO}_{4}^{2-}>\mathrm{BF}_{4}^{-}>\mathrm{PF}_{6}^{-}=\mathrm{OTf}^{-}$was obtained for this dynamic combinatorial system.

Finally, a detailed tranformation process from $\mathrm{Pd}_{7} \mathrm{~L}_{14}$ (6a) to $\mathrm{Pd}_{3} \mathrm{~L}_{6}$ was traced by titration experiments following the sequential addition of $\mathrm{NO}_{3}^{-}$(Fig. 5b,c). ${ }^{1} \mathrm{H} \mathrm{NMR}$ and ESI-TOF-MS showed that the transformation took place via a gradual shrinking of the macrocyclic framework. On the basis of a careful assignment of the NMR and ESI-TOF-MS signals (Supplementary Figs 59-70 and Supplementary Tables 5 and 6), it was found that after adding 1 eq. of $\mathrm{NO}_{3}^{-}\left(\left[\mathrm{NO}_{3}^{-}\right]:[\right.$ $\left.\left.\mathrm{PF}_{6}^{-}\right]=1: 14\right)$ the $\mathrm{Pd}_{7} \mathrm{~L}_{14}$ macrocycle starts to transform into $\mathrm{Pd}_{6} \mathrm{~L}_{12}$ and $\mathrm{Pd}_{4} \mathrm{~L}_{8}$, whose contents reach maxima when 3 eq. of $\mathrm{NO}_{3}^{-}$were added. Meanwhile, formation of $\mathrm{Pd}_{5} \mathrm{~L}_{10}$ was also detected starting from the addition of 2 eq. of $\mathrm{NO}_{3}^{-}$. All of these intermediates start to drop in contents after the most stable $\mathrm{Pd}_{3} \mathrm{~L}_{6}$ complex evolved in the system. We hypothesize that $\mathrm{NO}_{3}^{-}$anions are acting as hydrogon-bonding anchors which pull together the neighbouring $\mathrm{Pd}_{2} \mathrm{~L}_{2}$ square units on the framework, leading to a gradually shrinking of the ring size. The contents of $\mathrm{Pd}_{6} \mathrm{~L}_{12}$ and $\mathrm{Pd}_{4} \mathrm{~L}_{8}$ are aboundent during the transformation proecess, possibly due to the fact that they have even numbers of $\mathrm{Pd}_{2} \mathrm{~L}_{2}$ square units, which can maximize the number of $\mathrm{H}$ bonding with the $\mathrm{NO}_{3}^{-}$anchors. In contrast, the concentration of the $\mathrm{Pd}_{5} \mathrm{~L}_{10}$ intermediate, which has odd number of $\mathrm{Pd}_{2} \mathrm{~L}_{2}$ square units, was rather low (Supplementary Fig. 71).

In summary, a dynamic anion-adaptive self-assembly system was constructed consisting of a very simple ligand and $\mathrm{Pd}^{\mathrm{II}}$ ions. The anion-induced transformation between the $\mathrm{Pd}_{n} \mathrm{~L}_{2 n}$ species are reminiscent of the induced-fit guest-binding mechanism observed in nature. Moreover, this new class of donut-shaped assemblies 
provide unique tunable hydrogen-binding pockets, where we envisage molecular sensing/catalysis is possible to take place.

\section{Methods \\ Materials. Unless otherwise noted, all chemicals and solvents were purchased} from commercial corporations and used without further purification. Deuterated solvents were purchased from Admas and J\&K scientific.

NMR measurements. 1D and 2D NMR spectra were measured on a Bruker-BioSpin AVANCE Ш HD (400 MHz) spectrometer. ${ }^{1} \mathrm{H}$ NMR chemical shifts were determined with respect to residual solvent signals of the deuterated solvents used. DOSY spectra were applied to estimate the dynamic radius for the compounds 2, 3, 4, 5 and $\mathbf{6}$ according to the Stokes-Einstein equation (1). Where: $D$ is diffusion coefficient obtained from DOSY spectrum, $K_{B}$ is Boltzmann constant, $T$ is temperature, viscosity $\eta$ was tested to be $2.2 \mathrm{mPa}$ and $r$ is the estimated dynamic radius.

$$
D=\frac{T K_{B}}{6 \pi \eta r}
$$

MS measurements. ESI-Q-TOF mass spectra were recorded on an Impact II UHR-TOF mass spectrometry from Bruker, with ESI-L low concentration tuning mix (from Agilent Technologies) as the internal standard (Accuracy <3 p.p.m.). Data analyses and simulations of ESI-TOF mass spectra were processed on a Bruker Data Analysis software (Version 4.3). Molecular mechanical structure simulations were performed on a Material Studio v6.0 software using the build-in geometry optimization task based on the Universal forcefield.

Synthesis and characterization. $\left(\mathbf{P d}_{3} \mathrm{~L}_{6}\right)\left(\mathrm{NO}_{3}\right)_{6}$ (2) Ligand $\mathbf{1}$ (ref. 51) (4.98 mg, $20.07 \mu \mathrm{mol})$ was treated with $\mathrm{Pd}\left(\mathrm{NO}_{3}\right)_{2}(10.04 \mu \mathrm{mol})$ in $\left[\mathrm{D}_{6}\right] \mathrm{DMSO}(1 \mathrm{ml})$ at $70^{\circ} \mathrm{C}$ for $5 \mathrm{~h} .{ }^{1} \mathrm{H}$ NMR confirmed the quantitative formation of complex $2 .{ }^{1} \mathrm{H}$ NMR $\left(400 \mathrm{MHz},\left[\mathrm{D}_{6}\right] \mathrm{DMSO}, 298 \mathrm{~K}\right) \delta 8.99(\mathrm{~s}, 12 \mathrm{H}), 7.90(\mathrm{~d}, J=8.3 \mathrm{~Hz}, 12 \mathrm{H}), 7.66(\mathrm{~d}$, $J=8.3 \mathrm{~Hz}, 12 \mathrm{H}), 7.39(\mathrm{t}, J=7.8 \mathrm{~Hz}, 12 \mathrm{H}), 7.28(\mathrm{t}, J=7.8 \mathrm{~Hz}, 12 \mathrm{H}), 7.09(\mathrm{~d}$, $J=13.7 \mathrm{~Hz}, 6 \mathrm{H}), 6.55(\mathrm{~d}, J=14.0 \mathrm{~Hz}, 6 \mathrm{H}) .{ }^{13} \mathrm{C}$ NMR $\left(100 \mathrm{MHz},\left[\mathrm{D}_{6}\right] \mathrm{DMSO}\right.$, $298 \mathrm{~K}) \delta 145.39,138.88,130.67,125.99,124.90,117.77,111.82$ and 54.51(Supplementary Figs 1-3). ESI-TOF-MS $\left(\mathrm{NO}_{3}^{-}\right.$salt, $\left.\mathrm{CH}_{3} \mathrm{CN}\right)$ : the following picked signals are those at the highest intensities. $m / z$ Calcd for $\left[\mathrm{Pd}_{3} \mathrm{~L}_{6}\left(\mathrm{NO}_{3}^{-}\right)_{4}\right]^{2+}$ 1028.1513, found 1028.1468; Calcd for $\left[\mathrm{Pd}_{3} \mathrm{~L}_{6}\left(\mathrm{NO}_{3}^{-}\right)_{3}\right]^{3+} 665.1049$, found 665.1049 (Supplementary Fig. 5).

$\left(\mathbf{P d}_{\mathbf{6}} \mathbf{L}_{\mathbf{1 2}}\right)\left(\mathbf{B F}_{\mathbf{4}}\right)_{12}(5) \mathrm{PdCl}_{2}(17.73 \mathrm{mg}, 0.10 \mathrm{mmol})$ was dissolved in $\left[\mathrm{D}_{6}\right] \mathrm{DMSO}$ $(2 \mathrm{ml})$ and stirred for $10 \mathrm{~h}$ at room temperature with $\mathrm{AgBF}_{4}(38.94 \mathrm{mg}, 0.20 \mathrm{mmol})$. After removal of $\mathrm{AgCl}$ by filtration, the $\mathrm{Pd}\left(\mathrm{BF}_{4}\right)_{2}$ stock solution in $\left[\mathrm{D}_{6}\right] \mathrm{DMSO}$ was obtained quantitatively. Ligand $1(20.00 \mathrm{mg}, 80.60 \mu \mathrm{mol})$ was treated with $\mathrm{Pd}\left(\mathrm{BF}_{4}\right)_{2}$ $(40.30 \mu \mathrm{mol})$ in $\left[\mathrm{D}_{6}\right] \mathrm{DMSO}(1 \mathrm{ml})$ at $70^{\circ} \mathrm{C}$ for $5 \mathrm{~h}$. After addition of $0.3 \mathrm{ml} \mathrm{DCM}$ into the solution, a small amount of precipitation appeared which was then filtrated off and pure compound 5 in $\left[\mathrm{D}_{6}\right]$ DMSO was obtained after removal of DCM. The isolation yield of this compound is about $65 \% .{ }^{1} \mathrm{H}$ NMR $\left(400 \mathrm{MHz},\left[\mathrm{D}_{6}\right] \mathrm{DMSO}\right.$, $298 \mathrm{~K}) \delta 9.06(\mathrm{~s}, 12 \mathrm{H}), 9.00(\mathrm{~s}, 12 \mathrm{H}), 8.17(\mathrm{~d}, J=8.2 \mathrm{~Hz}, 12 \mathrm{H}), 7.63$ (dd, $J=17.0$, $8.0 \mathrm{~Hz}, 36 \mathrm{H}), 7.35(\mathrm{t}, J=7.8 \mathrm{~Hz}, 12 \mathrm{H}), 7.22(\mathrm{~d}, J=14.6 \mathrm{~Hz}, 12 \mathrm{H}), 6.99(\mathrm{t}, J=7.8 \mathrm{~Hz}$, $12 \mathrm{H}), 6.84(\mathrm{t}, J=7.5 \mathrm{~Hz}, 12 \mathrm{H}), 6.57(\mathrm{~d}, J=14.8 \mathrm{~Hz}, 12 \mathrm{H}), 6.09(\mathrm{~d}, J=8.2 \mathrm{~Hz}, 12 \mathrm{H})$. ${ }^{19} \mathrm{~F}$ NMR $\left(376 \mathrm{MHz},\left[\mathrm{D}_{6}\right] \mathrm{DMSO}, 298 \mathrm{~K}\right) \delta-147.31 .{ }^{13} \mathrm{C} \mathrm{NMR}(100 \mathrm{MHz}$, $\left.\left[\mathrm{D}_{6}\right] \mathrm{DMSO}, 298 \mathrm{~K}\right) \delta 146.12,144.82,138.32,138.20,132.34,128.63,126.92,126.53$, $126.02,125.64,117.88,117.39,111.96,110.55$ and 54.36 (Supplementary Figs 6-11). ESI-TOF-MS ( $\mathrm{BF}_{4}^{-}$salt, $\left.\mathrm{CH}_{3} \mathrm{CN}\right)$ : the following picked signals are those at the highest intensities. $m / z$ Calcd for $\left[\left(\mathrm{Pd}_{6} \mathrm{~L}_{12}\right)\left(\mathrm{BF}_{4}\right)_{9}\right]^{3+} 1466.2455$, found 1466.2397; Calcd for $\left[\left(\mathrm{Pd}_{6} \mathrm{~L}_{12}\right)\left(\mathrm{BF}_{4}\right)_{8}\right]^{4+}$ 1077.9331, found 1077.9288; Calcd for $\left[\left(\mathrm{Pd}_{6} \mathrm{~L}_{12}\right)\left(\mathrm{BF}_{4}\right)_{7}\right]^{5}+844.9456$, found 844.9425; Calcd for $\left[\left(\mathrm{Pd}_{6} \mathrm{~L}_{12}\right)\left(\mathrm{BF}_{4}\right)_{6}\right]^{6+}$ 689.7873, found 689.7848 (Supplementary Fig. 12).

$\left(\mathbf{P d}_{7} \mathbf{L}_{14}\right)\left(\mathbf{P F}_{6}\right)_{14}(\mathbf{6 a}) \mathrm{PdCl}_{2}(17.73 \mathrm{mg}, 0.10 \mathrm{mmol})$ was dissolved in DMSO $(2 \mathrm{ml})$ and stirred for $10 \mathrm{~h}$ at room temperature in dark with $\mathrm{AgPF}_{6}(50.57 \mathrm{mg}$, $0.20 \mathrm{mmol})$. After removal of $\mathrm{AgCl}$ by filtration, stock solution of $\mathrm{Pd}\left(\mathrm{PF}_{6}\right)_{2}$ in $\left[\mathrm{D}_{6}\right]$ DMSO was obtained quantitatively. Then ligand $1(20 \mathrm{mg}, 80.60 \mu \mathrm{mol})$ was treated with $\mathrm{Pd}\left(\mathrm{PF}_{6}\right)_{2}(40.30 \mu \mathrm{mol})$ in $\left[\mathrm{D}_{6}\right] \mathrm{DMSO}(1 \mathrm{ml})$ at $70^{\circ} \mathrm{C}$ for $5 \mathrm{~h} .{ }^{1} \mathrm{H} \mathrm{NMR}$ confirmed the quantitative formation of complex. ${ }^{1} \mathrm{H}$ NMR confirmed the quantitative formation of complex 6a. ${ }^{1} \mathrm{H}$ NMR $\left(400 \mathrm{MHz},\left[\mathrm{D}_{6}\right] \mathrm{DMSO}, 298 \mathrm{~K}\right) \delta$ $9.09(\mathrm{~s}, 14 \mathrm{H}), 9.00(\mathrm{~s}, 14 \mathrm{H}), 8.22(\mathrm{~d}, J=8.4 \mathrm{~Hz}, 14 \mathrm{H}), 7.76(\mathrm{~d}, J=8.2 \mathrm{~Hz}, 14 \mathrm{H}), 7.63$ $(\mathrm{t}, J=7.5 \mathrm{~Hz}, 14 \mathrm{H}), 7.42(\mathrm{~d}, J=12.7 \mathrm{~Hz}, 14 \mathrm{H}), 7.35(\mathrm{~d}, J=8.4 \mathrm{~Hz}, 14 \mathrm{H}), 7.30-7.22$ $(\mathrm{m}, 14 \mathrm{H}), 7.04(\mathrm{t}, J=7.6 \mathrm{~Hz}, 14 \mathrm{H}), 6.89(\mathrm{t}, J=7.6 \mathrm{~Hz}, 14 \mathrm{H}), 6.41(\mathrm{~d}, J=13.7 \mathrm{~Hz}$, $14 \mathrm{H}), 6.02(\mathrm{~d}, J=8.2 \mathrm{~Hz}, 14 \mathrm{H}) .{ }^{13} \mathrm{C}$ NMR $\left(100 \mathrm{MHz},\left[\mathrm{D}_{6}\right] \mathrm{DMSO}, 298 \mathrm{~K}\right) \delta 145.32$, 144.72 , 138.06, 137.49, 132.14, 128.38, 126.81, 125.89, 117.40, 116.90, 111.79, 110.31 and 54.16 (Supplementary Figs 13-15). ESI-TOF-MS $\left(\mathrm{PF}_{6}^{-}\right.$salt, $\left.\mathrm{CH}_{3} \mathrm{CN}\right)$ : the following picked signals are those at the highest intensities. $m / z$ Calcd for $\left[\left(\mathrm{Pd}_{7} \mathrm{~L}_{14}\right)\left(\mathrm{PF}_{6}\right)_{11}\right]^{3+}$ 1938.4758, found 1938.4852; Calcd for $\left[\left(\mathrm{Pd}_{7} \mathrm{~L}_{14}\right)\left(\mathrm{PF}_{6}\right)_{10}\right]^{4+}$ 1417.6157, found 1417.6235; Calcd for $\left[\left(\mathrm{Pd}_{7} \mathrm{~L}_{14}\right)\left(\mathrm{PF}_{6}\right)_{9}\right]^{5+} 1105.0996$, found 1105.1060; Calcd for $\left[\left(\mathrm{Pd}_{7} \mathrm{~L}_{14}\right)\left(\mathrm{PF}_{6}\right)_{8}\right]^{6+} 896.7555$, found 896.7605; Calcd for $\left[\left(\mathrm{Pd}_{7} \mathrm{~L}_{14}\right)\left(\mathrm{PF}_{6}\right)_{7}\right]^{7+} 747.9384$, found 747.9432 ; Calcd for $\left[\left(\mathrm{Pd}_{7} \mathrm{~L}_{14}\right)\left(\mathrm{PF}_{6}\right)_{6}\right]^{8+}$ 636.3255, found 636.3299 (Supplementary Fig. 20).
$\left(\mathbf{P d}_{7} \mathbf{L}_{14}\right)\left(\mathrm{CF}_{3} \mathrm{SO}_{3}\right)_{14}(6 \mathrm{~b}) \mathrm{PdCl}_{2}(17.73 \mathrm{mg}, 0.10 \mathrm{mmol})$ was dissolved in $\left[\mathrm{D}_{6}\right] \mathrm{DMSO}(2 \mathrm{ml})$ and stirred for $10 \mathrm{~h}$ at room temperature in dark with $\mathrm{AgCF}_{3} \mathrm{SO}_{3}$ $(51.39 \mathrm{mg}, 0.20 \mathrm{mmol})$. After removal of $\mathrm{AgCl}$ by filtration, the stock solution of $\mathrm{Pd}\left(\mathrm{CF}_{3} \mathrm{SO}_{3}\right)_{2}$ in $\left[\mathrm{D}_{6}\right] \mathrm{DMSO}$ was obtained quantitatively. Then ligand 1 (10 mg, $40.29 \mu \mathrm{mol})$ was treated with $\mathrm{Pd}\left(\mathrm{CF}_{3} \mathrm{SO}_{3}\right)_{2}(20.15 \mu \mathrm{mol})$ in $\left[\mathrm{D}_{6}\right] \mathrm{DMSO}(1 \mathrm{ml})$ at $70{ }^{\circ} \mathrm{C}$ for $5 \mathrm{~h} .{ }^{1} \mathrm{H}$ NMR confirmed the quantitative formation of complex $6 \mathbf{b} .{ }^{1} \mathrm{H}$ NMR $\left(400 \mathrm{MHz},\left[\mathrm{D}_{6}\right] \mathrm{DMSO}, 298 \mathrm{~K}\right) \delta 9.19(\mathrm{~d}, J=8.6 \mathrm{~Hz}, 28 \mathrm{H}), 8.21(\mathrm{~d}, J=8.2 \mathrm{~Hz}$, $14 \mathrm{H}), 7.72(\mathrm{~d}, J=7.9 \mathrm{~Hz}, 14 \mathrm{H}), 7.65-7.55(\mathrm{~m}, 14 \mathrm{H}), 7.40-7.28(\mathrm{~m}, 28 \mathrm{H}), 7.27-7.17$ $(\mathrm{m}, 14 \mathrm{H}), 7.07-6.96(\mathrm{~m}, 14 \mathrm{H}), 6.91-6.80(\mathrm{~m}, 14 \mathrm{H}), 6.53(\mathrm{~d}, J=14.5 \mathrm{~Hz}, 14 \mathrm{H}), 6.00$ $(\mathrm{d}, J=7.8 \mathrm{~Hz}, 14 \mathrm{H}) .{ }^{13} \mathrm{C}$ NMR $\left(100 \mathrm{MHz},\left[\mathrm{D}_{6}\right] \mathrm{DMSO}, 298 \mathrm{~K}\right) \delta 145.32,144.72$, $138.06,137.49,132.14,128.38,126.81,125.89,117.40,116.90,111.79,110.31$ and 54.16 (Supplementary Figs $16-18)$. ESI-TOF-MS $\left(\mathrm{CF}_{3} \mathrm{SO}_{3}^{-}\right.$salt, $\left.\mathrm{CH}_{3} \mathrm{CN}\right)$ : the following picked signals are those at the highest intensities. $\mathrm{m} / z$ Calcd for $\left[\left(\mathrm{Pd}_{7} \mathrm{~L}_{14}\right)\left(\mathrm{CF}_{3} \mathrm{SO}_{3}\right)_{11}\right]^{3+} 1953.4308$, found 1953.4414; Calcd for $\left[\left(\mathrm{Pd}_{7} \mathrm{~L}_{14}\right)\right.$ $\left.\left(\mathrm{CF}_{3} \mathrm{SO}_{3}\right)_{10}\right]^{4+} 1427.8350$, found 1427.8426; Calcd for $\left[\left(\mathrm{Pd}_{7} \mathrm{~L}_{14}\right)\left(\mathrm{CF}_{3} \mathrm{SO}_{3}\right)_{9}\right]^{5+}$ 1112.4775, found 1112.4827; Calcd for $\left[\left(\mathrm{Pd}_{7} \mathrm{~L}_{14}\right)\left(\mathrm{CF}_{3} \mathrm{SO}_{3}\right)_{8}\right]^{6+902.2392 \text {, found }}$ 902.2435; Calcd for $\left[\left(\mathrm{Pd}_{7} \mathrm{~L}_{14}\right)\left(\mathrm{CF}_{3} \mathrm{SO}_{3}\right)_{7}\right]^{7+} 751.9261$, found 751.9297; Calcd for $\left[\left(\mathrm{Pd}_{7} \mathrm{~L}_{14}\right)\left(\mathrm{CF}_{3} \mathrm{SO}_{3}\right)_{6}\right]^{8}+751.9261$, found 751.9297 ; Calcd for $\left[\left(\mathrm{Pd}_{7} \mathrm{~L}_{14}\right)\right.$ $\left.\left(\mathrm{CF}_{3} \mathrm{SO}_{3}\right)_{5}\right]^{9+}$ 639.3163, found 639.3199 (Supplementary Fig. 21).

$\left(\mathbf{P d}_{\mathbf{4}} \mathrm{L}_{\mathbf{8}}\right)\left(\mathbf{S O}_{4}\right)_{2}\left(\mathbf{B F}_{4}\right)_{4}(\mathbf{3})$ the solution of $\mathbf{5}(6.72 \mu \mathrm{mol})$ was treated with tetrabutylammonium hydrogen sulfate $(10.27 \mathrm{mg}, 30.24 \mu \mathrm{mol}, 4.50 \mathrm{eq}$. $)$ at $70^{\circ} \mathrm{C}$ for $3 \mathrm{~h} .{ }^{1} \mathrm{H}$ NMR confirmed the quantitative formation of complex $3 .{ }^{1} \mathrm{H}$ NMR $\left(400 \mathrm{MHz},\left[\mathrm{D}_{6}\right] \mathrm{DMSO}, 298 \mathrm{~K}\right) \delta 10.46(\mathrm{~s}, 16 \mathrm{H}), 9.30(\mathrm{~d}, J=8.4 \mathrm{~Hz}, 16 \mathrm{H}), 8.06$ $(\mathrm{d}, J=8.5 \mathrm{~Hz}, 16 \mathrm{H}), 7.46(\mathrm{t}, J=7.7 \mathrm{~Hz}, 16 \mathrm{H}), 7.36(\mathrm{t}, J=7.6 \mathrm{~Hz}, 16 \mathrm{H}), 7.16(\mathrm{~d}$, $J=15.4 \mathrm{~Hz}, 8 \mathrm{H}), 7.07(\mathrm{~d}, J=14.8 \mathrm{~Hz}, 8 \mathrm{H}) .{ }^{13} \mathrm{C}$ NMR $(100 \mathrm{MHz}, \mathrm{DMSO}, 298 \mathrm{~K})$ $\delta 145.61,138.53,132.16,125.77,124.92,118.68,112.05$ and 57.76 (Supplementary Figs 22-25). ESI-TOF-MS ( $\mathrm{SO}_{4}^{2-} / \mathrm{BF}_{4}^{-}$salt, $\left.\mathrm{CH}_{3} \mathrm{CN}\right)$ : the following picked signals are those at the highest intensities. $m / z$ Calcd for $\left[\left(\mathrm{Pd}_{4} \mathrm{~L}_{8}\right)\left(\mathrm{SO}_{4}\right)_{2}\left(\mathrm{BF}_{4}\right)_{2}\right]^{2+}$ 1388.6898, found 1388.6908; Calcd for $\left[\left(\mathrm{Pd}_{4} \mathrm{~L}_{8}\right)\left(\mathrm{SO}_{4}\right)_{2}\left(\mathrm{BF}_{4}\right)\right]^{3+} 896.7918$, found 896.7930; Calcd for $\left[\left(\mathrm{Pd}_{4} \mathrm{~L}_{8}\right)\left(\mathrm{SO}_{4}\right)_{2}\right]^{4+}$ 650.8428, found 650.8434 (Supplementary Figs 27 and 28).

$\left(\mathbf{P d}_{5} \mathbf{L}_{10}\right)\left(\mathbf{H M o}_{7} \mathbf{O}_{24}\right)\left(\mathbf{B F}_{4}\right)_{5}(4)$ the solution of $\mathbf{5}(6.72 \mu \mathrm{mol})$ was treated with tetrabutylammonium heptamolybdate $\left(13.48 \mathrm{mg}, 5.38 \mu \mathrm{mol}, 0.80\right.$ eq.) at $70{ }^{\circ} \mathrm{C}$ for $3 \mathrm{~h} .{ }^{1} \mathrm{H}$ NMR confirmed the quantitative formation of complex $4 .{ }^{1} \mathrm{H}$ NMR $\left(400 \mathrm{MHz},\left[\mathrm{D}_{6}\right] \mathrm{DMSO}, 298 \mathrm{~K}\right) \delta 10.01$ (ddd, $\left.J=65.3,61.9,39.5 \mathrm{~Hz}, 20 \mathrm{H}\right), 9.28$ $(\mathrm{t}, J=28.2 \mathrm{~Hz}, 20 \mathrm{H}), 8.21-7.91(\mathrm{~m}, 20 \mathrm{H}), 7.42(\mathrm{~d}, J=8.0 \mathrm{~Hz}, 20 \mathrm{H}), 7.37(\mathrm{~s}, 20 \mathrm{H})$, $7.18(\mathrm{~s}, 10 \mathrm{H}), 6.91(\mathrm{~s}, 10 \mathrm{H}) .{ }^{13} \mathrm{C}$ NMR $(100 \mathrm{MHz}, \mathrm{DMSO}, 298 \mathrm{~K}) \delta 144.61,138.26$ $130.82,125.10,124.49,119.10$ and 111.60 (Supplementary Figs 29-33). ESI-TOFMS $\left(\mathrm{HMo}_{7} \mathrm{O}_{24}^{5-}, \mathrm{BF}_{4}^{-}\right.$salt, $\left.\mathrm{CH}_{3} \mathrm{CN}\right)$ : the following picked signals are those at the highest intensities. $m / z$ Calcd for $\left[\left(\mathrm{Pd}_{5} \mathrm{~L}_{10}\right)\left(\mathrm{HMo}_{7} \mathrm{O}_{24}\right)\right]^{5+814.3625}$, found 814.3622; Calcd for $\left[\left(\mathrm{Pd}_{5} \mathrm{~L}_{10}\right)\left(\mathrm{HMo}_{7} \mathrm{O}_{24}\right)\left(\mathrm{BF}_{4}\right)\right]^{4+}$ 1039.7043, found 1039.7051; Calcd for $\left[\left(\mathrm{Pd}_{5} \mathrm{~L}_{10}\right)\left(\mathrm{HMo}_{7} \mathrm{O}_{24}\right)\left(\mathrm{BF}_{4}\right)_{2}\right]^{3+} 1414.9399$, found 1414.9400

(Supplementary Figs 35 and 36 ).

Transformation of $\mathbf{6}$ a into 5 by $\mathbf{B F}_{\mathbf{4}}^{-}: 35$ eq. of $\mathrm{N}\left(\mathrm{C}_{4} \mathrm{H}_{9}\right)_{4} \mathrm{BF}_{4}$ was added into the prepared solution of compound $\mathbf{6 a}$, followed by stirring for $3 \mathrm{~h}$ at $70{ }^{\circ} \mathrm{C}$. ${ }^{1} \mathrm{H} \mathrm{NMR}$ and ESI-TOF-MS spectra revealed that compound $\mathbf{6 a}$ changed into 5 (with mixed counter anions of $\mathrm{PF}_{6}^{-}$and $\mathrm{BF}_{4}^{-}$) in $80 \%$ yield (Supplementary Figs $42-44$ and Supplementary Table 5).

Transformation of $\mathbf{6 a}$ into $\mathbf{4}$ by $\mathbf{M o}_{7} \mathbf{O}_{24}^{\mathbf{6}-}: 0.8$ eq. of $\left[\mathrm{N}\left(\mathrm{C}_{4} \mathrm{H}_{9}\right)_{4}\right]_{6} \mathrm{Mo}_{7} \mathrm{O}_{24}$ was added into the prepared solution of compound $\mathbf{6 a}$, followed by stirring for $3 \mathrm{~h}$ at $70{ }^{\circ} \mathrm{C} .{ }^{1} \mathrm{H}$ NMR and ESI-TOF-MS spectra revealed that compound $\mathbf{6 a}$ quantitatively changed into 4 (with mixed counter anions of $\mathrm{PF}_{6}^{-}$and $\mathrm{HMo}_{7} \mathrm{O}_{24}^{--}$) (Supplementary Figs 36 and 45).

Transformation of $\mathbf{6 a}$ into 3 by $\mathbf{H S O}_{4}^{-}: 5.25$ eq. of $\mathrm{N}^{-}\left(\mathrm{C}_{4} \mathrm{H}_{9}\right)_{4} \mathrm{HSO}_{4}$ was added into the prepared solution of compound $6 \mathrm{a}$, followed by stirring for $3 \mathrm{~h}$ at $70^{\circ} \mathrm{C}$. The ${ }^{1} \mathrm{H}$ NMR and ESI-TOF-MS spectra revealed that the compound $\mathbf{6 a}$ quantitatively changed into 3 (with mixed counter anions of $\mathrm{PF}_{6}^{-}$and $\mathrm{SO}_{4}^{-}$) completely (Supplementary Figs 28 and 46).

Transformation of $\mathbf{6 a}$ into 2 by $\mathrm{NO}_{3}^{-}: 30$ eq. of $\mathrm{KNO}_{3}$ was added into the prepared solution of compound $\mathbf{6 a}$, followed by stirring for $3 \mathrm{~h}$ at $70^{\circ} \mathrm{C}$. The ${ }^{1} \mathrm{H}$ NMR and ESI-TOF-MS spectra revealed the compound $\mathbf{6 a}$ quantitatively changed into 2 (with mixed counter anions of $\mathrm{PF}_{6}^{-}$and $\mathrm{NO}_{3}^{-}$) completely (Supplementary Figs 47 and 48).

Transformation of 5 into 4 by $\mathbf{M o}_{7} \mathbf{O}_{24}^{\mathbf{6}-}: 0.8$ eq. of $\left[\mathrm{N}\left(\mathrm{C}_{4} \mathrm{H}_{9}\right)_{4}\right]_{6} \mathrm{Mo}_{7} \mathrm{O}_{24}$ was added into the prepared solution of compound 5, followed by stirring for $3 \mathrm{~h}$ at $70{ }^{\circ} \mathrm{C}$. The ${ }^{1} \mathrm{H}$ NMR and ESI-TOF-MS spectra revealed that compound $\mathbf{5}$ quantitatively changed into 4 (with mixed counter anions of $\mathrm{BF}_{4}^{-}$and $\mathrm{HMo}_{7} \mathrm{O}_{24}^{5-}$ ) (Supplementary Figs 49-35).

Transformation of 5 into 3 by $\mathbf{H S O}_{4}^{-}$: 4.5 eq. of $\mathrm{N}\left(\mathrm{C}_{4} \mathrm{H}_{9}\right)_{4} \mathrm{HSO}_{4}$ was added into the prepared solution of compound 5 , followed by stirring for $3 \mathrm{~h}$ at $70^{\circ} \mathrm{C}$. The ${ }^{1} \mathrm{H}$ NMR and ESI-TOF-MS spectra revealed the compound $\mathbf{5}$ quantitatively changed into 3 (with mixed counter anions of $\mathrm{BF}_{4}^{-}$and $\mathrm{SO}_{4}^{-}$) (Supplementary Figs 27 and 50).

Transformation of 5 into 2 by $\mathbf{N O}_{3}^{-}: 12$ eq. of $\mathrm{KNO}_{3}$ was added into the prepared solution of compound 5 , followed by stirring for $3 \mathrm{~h}$ at $70^{\circ} \mathrm{C}$. The ${ }^{1} \mathrm{H}$ NMR and ESI-TOF-MS spectra revealed the compound $\mathbf{5}$ quantitatively changed into 2 (with mixed counter anions of $\mathrm{BF}_{4}^{-}$and $\mathrm{NO}_{3}^{-}$) (Supplementary Figs 51 and 52).

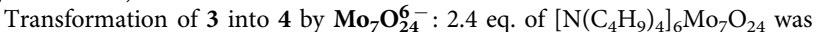
added into the prepared solution of compound 3, followed by stirring for $3 \mathrm{~h}$ at $70{ }^{\circ} \mathrm{C}$. The ${ }^{1} \mathrm{H}$ NMR and ESI-TOF-MS spectra revealed the compound 3 
quantitatively changed into 4 (with mixed counter anions of $\mathrm{HSO}_{4}^{-}, \mathrm{BF}_{4}^{-}$and $\mathrm{HMo}_{7} \mathrm{O}_{24}^{-}$) (Supplementary Figs 53 and 54).

Transformation of 3 into 2 by $\mathrm{NO}_{3}^{-}: 13.3$ eq. of $\mathrm{KNO}_{3}$ was added into the prepared solution of compound 3 , followed by stirring for $3 \mathrm{~h}$ at $70^{\circ} \mathrm{C}$. The ${ }^{1} \mathrm{H}$ NMR and ESI-TOF-MS spectra revealed the compound 3 quantitatively changed into 2 (with mixed counter anions of $\mathrm{HSO}_{4}^{-}, \mathrm{BF}_{4}^{-}$and $\mathrm{NO}_{3}^{-}$) (Supplementary Figs 56 and 55).


added into the prepared solution of compound 2 , followed by stirring for $3 \mathrm{~h}$ at $70{ }^{\circ} \mathrm{C}$. The ${ }^{1} \mathrm{H}$ NMR and ESI-TOF-MS spectra revealed that compound 2 quantitatively changed into 4 (with mixed counter anions of $\mathrm{NO}_{3}^{-}$and $\mathrm{HMo}_{7} \mathrm{O}_{24}^{5-}$ ) (Supplementary Figs 57 and 58).

Single crystal X-ray diffractions. The X-ray diffraction studies for complexes 2, 3, 4, 5 were carried out at the BL17B macromolecular crystallography beamline in SSRF. The collected diffraction data were processed with the HKL2000 software program ${ }^{52}$. All the structures were solved by direct methods and refined by full-matrix least-squares on $F^{2}$ with anisotropic displacement using the SHELX software package ${ }^{53}$.

The crystals of these kinds of giant supramolecular assemblies often diffract very weekly in nature. Some of the final $R$ factors were converged to very high values, because the crystal was diffracting very weakly due to a large amount of disordered/amorphous solvents and anions that could not be fully located. The electron residuals in such cases were removed by the SQUEEZE routine ${ }^{54}$. We tried our best to finish the refinement but still some A-alerts are found by the (IUCr) checkCIF routine, all of which are due to the poor diffraction nature of the crystals or the disorder of the solvents and anions. Details on crystal data collection and refinement were summarized in Supplementary Tables 1-4.

Crystal data for 2: space group $P-1, a=18.088(4) \AA, b=18.299(4) \AA$ $c=20.871(4) \AA, V=6,099(3) \AA^{3}, Z=2, T=80 \mathrm{~K}$. Anisotropic least-squares refinement for the framework atoms and isotropic refinement for the other atoms on 30,186 independent merged reflections $\left(R_{\text {int }}=0.0292\right)$ converged at residual $w R_{2}=0.3805$ for all data; residual $R_{1}=0.1126$ for 59494 observed data $[I>2 \sigma(I)]$, and goodness of fit $(\mathrm{GOF})=1.048$.

Crystal data for 3: space group P21c, $a=18.178(4) \AA, b=32.042(6) \AA$ $c=18.582(4) \AA, V=10,616(4) \AA^{3}, Z=2, T=293 \mathrm{~K}$. Anisotropic least-squares refinement for the framework atoms and isotropic refinement for the other atoms on 26,904 independent merged reflections $\left(R_{\text {int }}=0.0809\right)$ converged at residual $w R_{2}=0.2780$ for all data; residual $R_{1}=0.0765$ for 93,650 observed data $[I>2 \sigma(I)]$, and goodness of fit $(\mathrm{GOF})=1.042$.

Crystal data for 4: space group Pmmn, $a=20.3994(4) \AA, b=21.2991(4) \AA$, $c=29.5319(6) \AA, V=12,831.3(4) \AA^{3}, Z=2, T=293 \mathrm{~K}$. Anisotropic least-squares refinement for the framework atoms and isotropic refinement for the other atoms on 13,683 independent merged reflections $\left(R_{\text {int }}=0.0591\right)$ converged at residual $w R_{2}=0.5449$ for all data; residual $R_{1}=0.1540$ for 18,8179 observed data $[I>2 \sigma(I)]$, and goodness of fit $(\mathrm{GOF})=2.991$.

Crystal data for 5: space group $R-3 c, a=71.246(4) \AA, \mathrm{b}=71.246(4) \AA$, $c=27.0831(16) \AA, V=119056(15) \AA^{3}, Z=18, T=293 \mathrm{~K}$. Anisotropic

least-squares refinement for the framework atoms and isotropic refinement for the other atoms on 10,282 independent merged reflections $\left(R_{\text {int }}=0.145\right)$ converged at residual $w R_{2}=0.4507$ for all data; residual $R_{1}=0.1369$ for 96,189 observed data $[I>2 \sigma(I)]$, and goodness of fit $(\mathrm{GOF})=2.044$.

Data availability. The X-ray crystallographic coordinates for structures reported in this article have been deposited at the Cambridge Crystallographic Data Centre (CCDC), under deposition nos CCDC 1529252-1529255. These data can be obtained free of charge (http://www.ccdc.cam.ac.uk/data_request/cif). All other data are either provided in the Article and its Supplementary Information or are available on request.

\section{References}

1. Ballester, P., Fujita, M. \& Rebek, Jr. J. Molecular containers. Chem. Soc. Rev. 44, 392-393 (2015).

2. Cook, T. R. \& Stang, P. J. Recent Developments in the preparation and chemistry of metallacycles and metallacages via coordination. Chem. Rev. 115, 7001-7045 (2015).

3. Smulders, M. M. J., Riddell, I. A., Browne, C. \& Nitschke, J. R. Building on architectural principles for three-dimensional metallosupramolecular construction. Chem. Soc. Rev. 42, 1728-1754 (2013).

4. Saalfrank, R. W., Maid, H. \& Scheurer, A. Supramolecular coordination chemistry: the synergistic effect of serendipity and rational design. Angew. Chem. Int. Ed. 47, 8794-8824 (2008).

5. Han, M., Engelhard, D. M. \& Clever, G. H. Self-assembled coordination cages based on banana-shaped ligands. Chem. Soc. Rev. 43, 1848-1860 (2014).

6. Yoshizawa, M., Klosterman, J. K. \& Fujita, M. Functional molecular flasks: new properties and reactions within discrete, self-assembled Hosts. Angew. Chem-Int. Ed. 48, 3418-3438 (2009).

7. Brown, C. J., Toste, F. D., Bergman, R. G. \& Raymond, K. N. Supramolecular catalysis in metal-ligand cluster hosts. Chem. Rev. 115, 3012-3035 (2015).
8. Breiner, B., Clegg, J. K. \& Nitschke, J. R. Reactivity modulation in container molecules. Chem. Sci. 2, 51-56 (2011).

9. Galan, A. \& Ballester, P. Stabilization of reactive species by supramolecular encapsulation. Chem. Soc. Rev. 45, 1720-1737 (2016).

10. Koblenz, T. S. \& Wassenaar, J. Reek JNH. Reactivity within a confined self-assembled nanospace. Chem. Soc. Rev. 37, 247-262 (2008).

11. Fujita, M. et al. Molecular paneling via coordination. Chem. Commun. 2001, 509-518 (2001).

12. Yoshizawa, M. \& Klosterman, J. K. Molecular architectures of multi-anthracene assemblies. Chem. Soc. Rev. 43, 1885-1898 (2014).

13. Mosquera, J., Ronson, T. K. \& Nitschke, J. R. Subcomponent flexibility enables conversion between $D_{4}$-symmetric $\mathrm{Cd}^{\mathrm{II}}{ }_{8} \mathrm{~L}_{8}$ and $T$-symmetric $\mathrm{Cd}^{\mathrm{II}}{ }_{4} \mathrm{~L}_{4}$ assemblies. J. Am. Chem. Soc. 138, 1812-1815 (2016).

14. Koshland, D. E. The Key-Lock theory and the Induced Fit theory. Angew. Chem., Int. Ed. 33, 2375-2378 (1995).

15. Gale Philip, A., Howe Ethan, N. W. \& Wu, X. Anion receptor chemistry. Chem 1, 351-422 (2016).

16. Beer, P. D. \& Gale, P. A. Anion recognition and sensing: the state of the art and future perspectives. Angew. Chem.-Int. Ed. 40, 486-516 (2001).

17. Jia, C., Zuo, W., Zhang, D., Yang, X.-J. \& Wu, B. Anion recognition by oligo-(thio)urea-based receptors. Chem. Commun. 52, 9614-9627 (2016).

18. Custelcean, R. Anion encapsulation and dynamics in self-assembled coordination cages. Chem. Soc. Rev. 43, 1813-1824 (2014).

19. Steed, J. W. Coordination and organometallic compounds as anion receptors and sensors. Chem. Soc. Rev. 38, 506-519 (2009).

20. Beer, P. D. Transition-metal receptor systems for the selective recognition and sensing of anionic guest species. Acc. Chem. Res. 31, 71-80 (1998).

21. Langton, M. J., Serpell, C. J. \& Beer, P. D. Anion recognition in water: recent advances from a supramolecular and macromolecular perspective. Angew. Chem.-Int. Ed. 55, 4629-4629 (2016).

22. Amendola, V. \& Fabbrizzi, L. Anion receptors that contain metals as structural units. Chem. Commun. 513-531 (2009).

23. Hasenknopf, B. et al. Self-assembly of tetra- and hexanuclear circular helicates. J. Am. Chem. Soc. 119, 10956-10962 (1997).

24. Campbell, V. E. et al. Cascading transformations within a dynamic self-assembled system. Nat. Chem. 2, 684-687 (2010).

25. Riddell, I. A. et al. Five discrete multinuclear metal-organic assemblies from one ligand: deciphering the effects of different templates. J. Am. Chem. Soc. 135, 2723-2733 (2013).

26. Riddell, I. A. et al. Anion-induced reconstitution of a self-assembling system to express a chloride-binding $\mathrm{Co}_{10} \mathrm{~L}_{15}$ pentagonal prism. Nat. Chem. 4, 751-756 (2012).

27. Otto, S., Furlan, R. L. E. \& Sanders, J. K. M. Selection and amplification of hosts from dynamic combinatorial libraries of macrocyclic disulfides. Science 297, 590-593 (2002).

28. Lam, R. T. S. et al. Amplification of acetylcholine-binding catenanes from dynamic combinatorial libraries. Science 308, 667-669 (2005).

29. Corbett, P. T. et al. Dynamic combinatorial chemistry. Chem. Rev. 106, 3652-3711 (2006).

30. Wang, W., Wang, Y.-X. \& Yang, H.-B. Supramolecular transformations within discrete coordination-driven supramolecular architectures. Chem. Soc. Rev. 45 2656-2693 (2016).

31. Campos-Fernández, C. S. et al. Anion template effect on the self-assembly and interconversion of metallacyclophanes. J. Am. Chem. Soc. 127, 12909-12923 (2005).

32. Riddell, I. A. et al. Cation- and anion-exchanges induce multiple distinct rearrangements within metallosupramolecular architectures. J. Am. Chem. Soc 136, 9491-9498 (2014)

33. Carnes, M. E., Collins, M. S. \& Johnson, D. W. Transmetalation of selfassembled, supramolecular complexes. Chem. Soc. Rev. 43, 1825-1834 (2014).

34. Lusby, P. J., Muller, P., Pike, S. J. \& Slawin, A. M. Z. Stimuli-responsive reversible assembly of $2 \mathrm{D}$ and $3 \mathrm{D}$ metallosupramolecular architectures. J. Am. Chem. Soc. 131, 16398-16400 (2009).

35. Tominaga, M. et al. Finite, spherical coordination networks that self-organize from 36 small components. Angew. Chem.-Int. Ed. 43, 5621-5625 (2004).

36. Suzuki, K., Tominaga, M., Kawano, M. \& Fujita, M. Self-assembly of an $\mathrm{M}_{6} \mathrm{~L}_{12}$ coordination cube. Chem. Commun. 2009, 1638-1640 (2009).

37. Sun, Q.-F. et al. Self-assembled $\mathrm{M}_{24} \mathrm{~L}_{48}$ polyhedra and their sharp structural switch upon subtle ligand variation. Science 328, 1144-1147 (2010).

38. Sun, Q.-F., Sato, S. \& Fujita, M. An $\mathrm{M}_{18} \mathrm{~L}_{24}$ stellated cuboctahedron through post-stellation of an $\mathrm{M}_{12} \mathrm{~L}_{24}$ core. Nat. Chem. 4, 330-333 (2012).

39. Sun, Q.-F., Murase, T., Sato, S. \& Fujita, M. A sphere-in-sphere complex by orthogonal self-assembly. Angew. Chem. Int. Ed. 50, 10318-10321 (2011).

40. Sun, Q.-F., Sato, S. \& Fujita, M. An $\mathrm{M}_{12}(\mathrm{~L} 1)_{12}(\mathrm{~L} 2)_{12}$ cantellated tetrahedron: a case study on mixed-ligand self-assembly. Angew. Chem. Int. Ed. 53, 13510-13513 (2014).

41. Fujita, D. et al. Self-assembly of $\mathrm{M}_{30} \mathrm{~L}_{60}$ icosidodecahedron. Chem 1, 91-101. 
42. Fujita, D. et al. Self-assembly of tetravalent Goldberg polyhedra from 144 small components. Nature 540, 563-566 (2016).

43. Zhang, G.-L., Zhou, L.-P., Yuan, D.-Q. \& Sun, Q.-F. Bottom-Up construction of mesoporous nanotubes from 78-component self-assembled nanobarrels. Angew. Chem. Int. Ed. 54, 9844-9848 (2015).

44. Xie, T.-Z., Guo, C., Yu, S.-Y. \& Pan, Y.-J. Fine-tuning conformational motion of a self-assembled metal-organic macrocycle by multiple C-Hösssanion hydrogen bonds. Angew. Chem. 124, 1203-1207 (2012).

45. Yao, L.-Y., Qin, L., Xie, T.-Z., Li, Y.-Z. \& Yu, S.-Y. Synthesis and anion sensing of water-soluble metallomacrocycles. Inorg. Chem. 50, 6055-6062 (2011).

46. Zhou, L.-P. \& Sun, Q.-F. A self-assembled $\mathrm{Pd}_{2} \mathrm{~L}_{4}$ cage that selectively encapsulates nitrate. Chem. Commun. 51, 16767-16770 (2015).

47. Yoon, J., Kim, S. K., Singh, N. J. \& Kim, K. S. Imidazolium receptors for the recognition of anions. Chem. Soc. Rev. 35, 355-360 (2006).

48. Don, A. \& Weakley, T. J. R. Guanidinium heptamolybdate monohydrate. Acta Crystallogr. B 37, 451-453 (1981).

49. Garin, J. L. \& Solar, M. A. Synthesis and crystal symmetry of a monoclinic modification of $\mathrm{MoO}_{3} \cdot \mathrm{H}_{2} \mathrm{O}$. Acta Crystallogr. A 40, C229 (1984).

50. Spek, A. PLATON SQUEEZE: a tool for the calculation of the disordered solvent contribution to the calculated structure factors. Acta Crystallogr. Sect. C 71, 9-18 (2015).

51. Ahmed, N., Shirinfar, B., Youn, I. S., Yousuf, M. \& Kim, K. S. Selective detection of guanosine-5'-triphosphate and iodide by fluorescent benzimidazolium-based cyclophanes. Org. Bio. Chem. 11, 6407-6413 (2013).

52. Otwinowski, Z. \& Minor, W. in Processing of X-ray Diffraction Data Collected in Oscillation Mode, Methods in Enzymology. Macromolecular Crystallogr, Part A. Vol. 276 (eds Carter C. W. J. \& Sweet R. M.) 307-326 (Academic Press, 1997).

53. Sheldrick, G. M. A short history of SHELX. Acta Crystallogr. Sect. A 64, 112-122 (2008).

54. Spek, A. L. Single-crystal structure validation with the program PLATON. J. Appl. Crystallogr. 36, 7-13 (2003).

\section{Acknowledgements}

This work was supported by the Strategic Priority Research Program of the Chinese Academy of Sciences (Grant No. XDB20000000), the National Natural Science Foundation of China (Grant nos. 21521061, 21402201, 21471150, 21601183), Natural Science Foundation of Fujian Province (Grant nos. 2016J06005, 2016J05051). Q.-F.S. is grateful for the award from 'The Recruitment Program of Global Youth Experts'. We thank the staff of BL17B beamlines at National Centre for Protein Sciences Shanghai and Shanghai Synchrotron Radiation Facility, Shanghai, People's Republic of China, for assistance during data collection. We also acknowledge Professor Makoto Fujita for helpful discussion.

\section{Author contributions}

Q.-F.S. proposed the ideas and supervised the project, T.Z. performed all the synthesis, L.-P. Z. contributed the mass measurements, X.-Q.G. and L.-X.C. contributed to the $\mathrm{X}$-ray data collection, Q.-F.S. solved all the crystal structures and wrote the manuscript with the input from all others.

\section{Additional information}

Supplementary Information accompanies this paper at http://www.nature.com/ naturecommunications

Competing interests: The authors declare no competing financial interests.

Reprints and permission information is available online at http://npg.nature.com/ reprintsandpermissions/

How to cite this article: Zhang, T. et al. Adaptive self-assembly and induced-fit transformations of anion-binding metal-organic macrocycles. Nat. Commun. 8, 15898 doi: $10.1038 /$ ncomms15898 (2017).

Publisher's note: Springer Nature remains neutral with regard to jurisdictional claims in published maps and institutional affiliations.

(c) (i) Open Access This article is licensed under a Creative Commons Attribution 4.0 International License, which permits use, sharing, adaptation, distribution and reproduction in any medium or format, as long as you give appropriate credit to the original author(s) and the source, provide a link to the Creative Commons license, and indicate if changes were made. The images or other third party material in this article are included in the article's Creative Commons license, unless indicated otherwise in a credit line to the material. If material is not included in the article's Creative Commons license and your intended use is not permitted by statutory regulation or exceeds the permitted use, you will need to obtain permission directly from the copyright holder. To view a copy of this license, visit http://creativecommons.org/ licenses/by/4.0/

(C) The Author(s) 2017 